\title{
Correction to: KSR1 regulates BRCA1 degradation and inhibits breast cancer growth
}

J. Stebbing • H. Zhang • Y. Xu • L. C. Lit • A. R. Green • A. Grothey • Y. Lombardo • M. Periyasamy • K. Blighe • W. Zhang · J. A. Shaw $\cdot$ I. O. Ellis $\cdot$ H. J. Lenz $\cdot$ G. Giamas

Published online: 22 April 2021

(c) The Author(s), under exclusive licence to Springer Nature Limited 2021

Correction to: Oncogene

https://doi.org/10.1038/onc.2014.129

Following the publication of this article, the authors noted an error in the labelling of cell lines. Figure $2 \mathrm{a}$ and respective legend should be labelled as MDA231 cells, not T47D. Supplementary Fig. 3 and respective legend should be labelled as T47D cells, not as MDA231. This clarification is important to elucidate the use of similar blots in Figs. 2a and 4b following KSR1 silencing in MDA231 cells. 